\title{
Constitutions and Crisis
}

\author{
Christopher J. Coyne* \\ George Mason University \\ Department of Economics \\ Fairfax, VA 22030 \\ ccoyne3@gmu.edu
}

\begin{abstract}
A crisis is an unexpected event that creates uncertainty and poses a direct or perceived threat to the goals and norms of an organization or society. While crises are ubiquitous, how societies respond to crises, and the way crises affect societies, is largely a matter of constitutional political economy. Drawing on a variety of insights from James Buchanan's research, this paper develops the political economy of crisis. Focus is placed on understanding: (1) how existing rules influence how societies cope with crises, (2) how crises can affect rules, and (3) the potential for the reform of rules in the wake of crises.
\end{abstract}

JEL Codes: D72, D78, H10

Keywords: constitution, crisis, political economy, protective state, productive state, rules

\footnotetext{
* The author was a Visiting Scholar at the Social Philosophy and Policy Center at Bowling Green State University when this paper was initially written.
} 


\section{Introduction}

A crisis is an unexpected event that creates uncertainty and poses a direct or perceived threat to the goals and norms of an organization or society (Seeger, Sellnow and Ulmer 1998; Boin, Stern and Sundelius 2005). The onset of a crisis typically requires an urgent response to minimize the associated damage. Examples of crises would include, but are not limited to, actual or threatened war and conflict (international and domestic), man-made disasters, natural disasters, and severe economic shocks. ${ }^{1}$

While crises are ubiquitous, how societies respond to crises, and the way crises affect societies, is largely a matter of constitutional political economy and the rules governing social and political interactions. Rules find their reason in the need to create parameters on both private and public activity to establish and maintain social harmony and peace (Brennan and Buchanan 1985: ix). Constitutional rules can be informal in nature-i.e., norms, conventions, and unwritten constitutions — or they can be formally codified in a written constitution.

Rules and crisis are related in several ways. For example, effective rules that channel government behaviors toward productive activities can mitigate the adverse effects of crisis through the creation of wealth, allowing for greater investment in infrastructure and crisis preparation and management. Similarly, rules limiting the predatory proclivities of government can minimize the possibility of certain types of crisis-e.g., economic collapse, genocide, forced displacement of citizens, etc.

\footnotetext{
${ }^{1}$ Many policy issues do not fit the definition of crisis since they are known and do not pose an immediate threat to the core of society. For example, many of the issues associated with government's unfunded liabilities are wellknown and, hence, are currently public policy problems instead of crises. That said, if known problems are left unaddressed, they can potentially result in crisis, as illustrated by the current debt crisis in Greece. In other words, a confluence of factors over time can trigger the onset of a crisis (see Diamond 2005). This highlights the difficulty with crisis prediction - given the sheer complexity of systems, no one knows when a problem will turn into a crisis.
} 
The onset of crisis can influence rules in two ways. First, a crisis can illustrate deficiencies within government that can result in institutional changes within the existing political constitution, which governs the activities of rule makers. An example would be the creation or reform of agencies to deal with crisis. Second, the urgency of a crisis can lead to changes in the political constitution itself. These changes may involve actual amendments to the constitution, but more commonly involves new and expanded interpretations of the scope of government powers as defined by the political constitution. From the standpoint of constitutional political economy, the main threat posed by crises is that they will erode the rules established by the political constitution which constrains state activity, resulting in constitutional anarchy.

There is an existing literature on the political economy of crisis. Higgs (1987) provides an ideological account of how crisis can lead to increases in the size of government. He argues that, in the wake of crisis, citizens demand that government "do something," ultimately leading to an increase in the size of government that persists in the post-crisis period. Posner (2004) applies some basic insights from public choice theory to explain why societies do not pay more attention to the threat, however small, of catastrophic risks. Congleton (2005) explores democratic decision-making in the wake of crisis and concludes that it is more prone to error due to less information and the absence of a clear electoral mandate.

There is also literature by scholars exploring various aspects of particular crises, such as Hurricane Katrina (see Congleton 2006; Shughart 2006; Sobel and Leeson 2006; ChamleeWright and Storr 2010). Finally, an existing literature also explores various political aspects of financial crises (see, for instance, Haggard 2000; Hausken and Plumper 2002; Satyanath 2005; Keefer 2007; Congleton 2009). 
This paper contributes to the existing literature on the political economy of crisis by exploring the connection between constitutional rules and crises. I provide insight into (1) how existing rules influence how societies cope with crises, (2) how crises can affect rules, and (3) the potential for reforming rules in the wake of crises. I draw on a range of insights from James Buchanan's body of research to develop a theory of the political economy of crisis. My analysis is applicable to a variety of different levels and types of social and political organization, as well as to a variety of crisis situations.

I proceed as follows. Section 2 focuses on choices within rules as they relate to crisis. I consider a model of the ideal protective-productive state, which serves a baseline for the firstbest conditions for a society to cope with crisis. I then consider what deviations from this model imply for a society's ability to deal with crisis. Section 3 considers how crisis can affect the rules themselves. These changes can occur on two levels. State actors, abiding by the existing political constitution, may change the rules facing private citizens. It is also possible, however, that a crisis might lead to changes in the political constitution, or meta-rules, governing the scope of state activity. I then turn to a consideration of the potential for constitutional reform-both within and over the rules - in post-crisis situations in Section 4. Section 5 concludes with the implications of the analysis.

\section{The Role of Rules in Coping with Crisis}

\subsection{The Ideal Protective-Productive State}

According to Buchanan (1975: 88-90) the protective state emerges at the constitutional level and is independent of the individuals involved. Its purpose is to enforce rights and agreed-upon contracts. The purpose of the protective state is to guard people from the perils of anarchy on the 
one hand and the threat of coercion by the state on the other. The productive state, in contrast, involves the production of public goods in the post-constitutional stage. These collective choices regarding what specific goods the state will produce are made within the rules set out in the overarching political constitution.

I begin with a model of the ideal protective-productive state. In this model property rights are well-defined, and the protective state effectively guards these rights by binding political rulers and by providing a legal system that enforces contracts. Further, within this model rules exist such that the productive state "...enables the community of persons to increase their overall levels of economic well-being, to shift toward the efficiency frontier" (Buchanan 1975: 124). Finally, the ideal model is characterized by the existence of effective mechanisms allowing citizens to monitor and reward or punish politicians. The ideal protective-productive state can mitigate the negative effects of crisis through four potential channels.

First, by protecting property rights, the ideal protective-productive state provides an incentive for entrepreneurs to continually allocate resources to their highest value use, resulting in the creation of wealth. An existing literature indicates that private property rights are crucial for economic growth and development (see, for example, Easton and Walker 1997; Scully, 1998; Hall and Jones 1999; Acemoglu and Robinson 2005). In the context of crises, higher levels of wealth matter because they allow more resources to be used for crisis prevention and to deal with crises when they do occur. Greater wealth also matters because it allows societies to invest more resources in quality building materials and infrastructure, which can offset some of the negative effects of natural disasters. For example, Kahn (2005) finds that countries with higher levels of development tend to suffer fewer deaths when natural disasters strike. 
Second, the ideal protective-productive state provides an incentive for crisis-specific entrepreneurship. In addition to creating an incentive for general wealth creation, the ideal protective-productive state encourages entrepreneurs to innovate in anticipation of future crisis. Further, once a crisis occurs, the ideal protective-productive state provides entrepreneurs with the incentive to alleviate the negative effects of crisis through the reallocation of resources.

For example, Horwitz (2009) discusses how Wal-mart responded both before Hurricane Katrina made landfall and after the storm ended. Prior to the landfall of the storm, Wal-mart had already triggered its existing emergency contingency plans which included moving machinery, such as generators, and key items, such as ice and water, into the threatened areas so that stores could remain open for as long as possible and quickly reopen after the storm. Indeed, within ten days after the hurricane struck, 111 of the 126 stores closed during the peak of the storm were reopened. In addition to providing for-profit services, Wal-mart also offered an array of free emergency goods, such as prescription drugs, to those hit by the hurricane. Wal-mart's pre- and post-hurricane response provides one indication of how well-defined and enforced property rights provide entrepreneurs with the incentive to anticipate and respond to crises in ways that mitigate costs.

In general, entrepreneurs will have the incentive to anticipate and respond to crises when property rights are well-defined and enforced and when the price mechanism is allowed to operate. Hayek (1960) argued for the importance of property and liberty so that people can discover what they do not already know. The process of discovering and sharing new knowledge — both scientific and tacit knowledge — was, for Hayek, the driving force behind the advancement of civilization. Precisely because crises are unpredictable events, creating an institutional environment conducive to the discovery of solutions to the unknown is of 
paramount importance. Discovery can take place through for-profit entrepreneurship as well as social entrepreneurship and civil society, which is a third channel through which the ideal protective-productive state can contribute to mitigating the negative effects of crises.

The notion of the "art of association" can be traced back to Tocqueville (1835/1839), who noted America's robust civil society that consists of an array of social associations and networks. These associations and networks were not the result of government design or legislation, but instead evolved through the ingenuity of self-reliant citizens acting entrepreneurially. Associations stand between the government and the market. They allow people to come together and solve common problems without relying on government. In doing so, they serve as a check on government power because private individuals do not become overly reliant on government to solve the problems they face. The emergence of a robust civil society is only possible when people's right to free association are established and protected. Where this right exists, people can invest in establishing social associations and networks, which can potentially play a crucial role in the wake of crises.

For example, Beito (1999) discusses how mutual aid societies in nineteenth century America provided financial support in the wake of local crises such as fires and epidemics. Chamlee-Wright and Storr (2010) and Chamlee-Wright (2010) highlight the importance of letting private stakeholders fill the "civil society vacuum" in the wake of natural disasters because they possess the knowledge and incentive to best rebuild. This research illustrates the importance of the state providing an institutional environment conducive to the formation of social networks prior to the onset of crisis, as well as providing citizens with the opportunity to take advantage of existing networks post crisis. 
Finally, the ideal protective-productive state can lessen the adverse effects of crises by ensuring that those in power provide value-added, crisis-related goods and services in an effective manner. The productive state, acting within established rules of collective decisionmaking, provides goods which increase the economic wellbeing of citizens. It also includes mechanisms that allow citizens to obtain information regarding the actions of political rulers and the means to reward or punish them accordingly. To understand why these mechanisms are important, consider the well-known principal-agent problem whereby effective political action requires that principals - i.e., voters - are able to effectively monitor their agents-i.e., elected politicians. Imperfect information on the part of voters threatens accountability, as does the absence of mechanisms for rewarding or punishing politicians.

Sen (1984: 84) captures the importance of information and punishment mechanisms in the context of crises when he writes, "India has not had a famine since independence, and given the nature of Indian politics and society, it is not likely that India can have a famine even in years of great food problems. The government cannot afford to fail to take prompt action when largescale starvation threatens. Newspapers play an important part in this, in making the facts known and forcing the challenge to be faced." Sen's main point, which has been empirically verified by Besley and Burgess (2002), is that political competition, combined with mechanisms for disseminating information, is critical for ensuring accountability of those in political power.

In general, the ideal protective-productive state provides mechanisms to ensure that the crisis-related activities of government are what citizens demand. Crisis-related activities assigned to the state may include, but are not limited to, crisis preparation-e.g. establishing agencies tasked with disaster response, formulating contingency plans, etc. - crisis preventione.g., forecasting potential crises and taking active steps for avoidance, etc. - and responding to 
potential and actual crises-e.g., evacuating citizens prior to crisis, quickly deploying rescue services and resources in the immediate wake of crisis, providing resources to rebuild, etc. Moreover, the ideal protective-productive state includes mechanisms for ensuring transparency and the means for citizens to reward or punish politicians depending on their effectiveness in meeting citizen demands as they relate to crises. In doing so, the ideal protective-productive model represents the best-case scenario for a society's ability to cope with crisis. $^{2}$

\subsection{Deviations from the Ideal}

Real-world governments deviate from the ideal protective-productive state. Deviations can negatively affect the four channels discussed above and, in doing so, weaken the ability of society to cope with crises when they occur. Deviations from the ideal model can occur for a variety of reasons. For one, property rights might be incomplete or weakly enforced. The absence of property rights weakens the incentive for entrepreneurship and hampers the process of wealth creation. Rights may also be curtailed by laws limiting the freedom of association, which limits the development of a robust civil society.

Even where property rights are relatively well-defined and enforced, the industrial organization of political institutions may cause deviations from the ideal model in at least three ways. First, the problems of economic calculation, information and incentives facing government bureaucrats have been well documented (see Mises 1994, Tullock 1965, and Niskanan 1971) and limit the effectiveness of government agencies in delivering goods and services demanded by citizens.

\footnotetext{
${ }^{2}$ This is not to imply that societies characterized by the ideal model would be completely insulated from crises. In complex systems, the onset and magnitude of crises are nearly impossible to predict and a relatively minor shock can potentially have large and disproportionate effects. In the extreme case, shocks can lead to the collapse of societies (see Ferguson 2010).
} 
Second, mechanisms fostering transparency and the flow of information regarding government performance are often weak or absent. For example, Coyne and Leeson (2009) analyze the many ways that governments can indirectly or directly control the media in order to influence the information available to citizens. When the state limits information flows, it weakens the ability of citizens to effectively monitor and punish politicians.

Third, the public choice issues of democratic politics - rational ignorance, the logic of special interest groups, etc. - can weaken the voting booth as a mechanism of reward and punishment, further limiting the responsiveness of government to citizen demands. The urgency associated with the onset of a crisis creates an additional information issue. During times of crisis, politicians still seek to satisfy key voters, but given he urgency of the situation they may not have the time to gauge actual voter wants (see Congleton 2005). This increases the chance of policy error during crisis.

Regulations and laws limiting private economic interactions are another source of deviation from the ideal model. For example, building regulations-e.g., permits, licenses, etc. - in the wake of natural disasters can greatly slow the process of private citizens rebuilding their communities (see Chamlee-Wright and Storr 2010 and Chamlee-Wright 2010). Price controls, such as 'anti-price gouging laws,' hamper the use of the price mechanism by entrepreneurs to reallocate goods and services to those most in need following a natural disaster. Finally, potential or actual government regulations in the wake of economic crisis can create 'regime uncertainty' which can have the counterproductive effect of slowing economic recovery due to a weakening of the incentive to act entrepreneurially (see Higgs 1997).

Deviations from the ideal model weaken some, or all, of the four channels discussed in the previous sub-section, hampering a society's ability to cope with crises. The further a state 
deviates from the ideal model, the less resilient it will be to the onset of a crisis. The extreme deviation from the ideal model is the purely predatory state that fails to recognize citizen rights and is purely unproductive in its activities. Societies with predatory states will be the least resilient to crisis, as illustrated by the recent earthquake in Haiti.

\section{How Crisis Can Affect Rules}

The way that societies cope with crises is a function of the existing rules. At the same time, the process of coping with crises can also influence the rules themselves, causing further deviation from the ideal model of the protective-productive state. These changes can take place at two levels.

First, government legislators acting within the existing political constitution (the meta rules) may change the rules that constrain the behavior of citizens acting in their private capacity. The new, post-9/11 regulations passed by the Federal Aviation Administration regarding airport security are an example of this logic. These new rules do not represent changes to the political constitution itself, but rather changes to the rules facing private citizens.

Second, changes can occur in the political constitution governing rule makers. This can occur through actual changes - e.g., amendments - to the rules, but it more commonly occurs through new and expanded interpretations of what the scope of the existing political constitution entails. For example, Siegan (2006) argues that starting in the 1930s, the U.S. Supreme Court shifted its interpretation of the U.S. Constitution from one centered on protecting property rights and free enterprise, to one condoning the expansion of state power over private property and markets. This new interpretation of state powers changed the political constitution within which legislators acted and granted them expanded power to make rules governing private action. 
Changes within and over the rules are often related. For example, following the onset of a crisis, a government may expand the scope of activities of existing agencies or create entirely new agencies and regulations concerning private behavior. These expanded activities create rules that regulate private citizens while also representing an expanded interpretation of state activities under the existing political constitution. In such instances both sets of rules - the rules created within the overarching political constitution and the interpretation of the political constitution itself-will have changed. For example, Corwin (1947) traces how government actions taken during World War II led to fundamental changes in the ability of the state to condemn property for its use during wartime. These expansions in government power, which were not overturned by the courts, resulted in changes to both the rules facing private citizens and an expanded interpretation of the scope of government granted by the existing political constitution.

There are several factors that can contribute to changes, and the reinforcement of those changes, in the scope of state activity during crisis. First, crises can lead to changes in ideology regarding the acceptable scope of state activity (Higgs 1987). The onset of a crisis leads to demands from citizens for government to respond with a sense of urgency, coupled with a willingness of citizens to grant state officials expanded discretionary powers to do so (Higgs 2007). This discretionary power leads to increased government activities, the costs of which are largely hidden from voters due to imperfect information. When the crisis ends, some crisis measures are fully repealed. However, others remain either in the same form or in a modified form, increasing the scope of state activities. Over time, citizens start to view these expanded activities as a normal part of life. In some cases measures taken during times of crisis are reviewed by the courts for their constitutionality. Where crisis measures are upheld by courts, it 
provides further legitimacy to the expanded scope of state activity and serves as a precedent for future cases regarding the lawfulness of expanded state activities (see Higgs 2009: 9-10). Even in cases where crisis measures are repealed in the post-crisis period, they can create a precedent for expanded state activities in future periods of potential or actual crisis.

Second, the creation of new or expanded crises-related agencies and bureaucracies creates a new set of vested interests who will seek to maintain their expanded power after the crisis concludes. Third, in providing an urgent response to a crisis, the state creates new opportunities for rent-seeking. The role of interest group pressures on politics is well-established in the public choice literature (see Buchanan, Tollison and Tullock 1980). However, as Navarro (1984: 45) notes, "the government is not only the target of special interest pressure, but also one of its biggest instigators." The urgency of government to do something during a crisis opens the window to a variety of new special interests, which can persist after the crisis ends. For example, Mueller (2006) notes the rise of a "terrorism industry" in the wake of the 9/11 attacks and explores how the members of this industry overstate the threat of terrorist attacks in order to secure additional resources.

The ultimate threat of increases in the scope of state power is the "constitutional anarchy" that Buchanan (1975) identified in the United States following the Great Depression. Under constitutional anarchy, “...the range and extent of federal government influence over individual behavior depend largely on the accidental preferences of politicians in judicial, legislative, and executive positions of power" (Buchanan 1975: 19). In times of crisis, the demand for urgent action on the part of government, combined with the likelihood of mistaken policy because of haste, makes it more likely that constitutional anarchy will result. The onset of constitutional anarchy threatens to push a society further from the conditions described by the ideal protective- 
productive model, further threatening the ability of societies to effectively cope with future crises.

\section{Crisis as an Opportunity for the Reform of Rules}

Mancur Olson (1984: 225) noted that extreme events could offer societies the potential of a “...clean institutional slate." According to Olson, the accumulation of interest groups in democratic societies is a driving factor behind economic decline. As the recent riots in Greece in response to proposed government budget reductions indicate, vested interests are typically unwilling to surrender their privileged position, even in the face of a crisis. Olson argued that the onset of a significant crisis resulting in collapse could displace these vested interests, allowing for widespread changes to institutions and rules. More recently, this same logic has been used by politicians and commentators in regards to Haiti, where it has been argued that the silver lining of the 2010 earthquake is the potential to build better institutions. There are clear cases of successful institutional rebuilding following crises such as post-World War II Germany and Japan. At the same time, there are many examples of failed attempts of rule reform (see, for example, Coyne 2008). What contributes to the ability of societies to reform rules following a crisis?

A starting point is Buchanan's continued emphasis that social analysis must "start from the here and now" (Buchanan 2004: 133). The logic is straightforward-in order to understand what reforms are feasible, the analyst has to understand the institutions as they currently exist. Focusing on the status quo clarifies the existing institutional constraints, which include evolved cultural rules and historical experiences. This insight allows us to establish the institutional status quo as the 'outer bound' for the reform of rules in the wake of crisis and allows us to make 
the following conjecture regarding reform. Reforms that neglect the "here and now" will be more likely to fail as compared to reforms grounded in an appreciation of the status quo.

This may seem obvious, but consider that many reform proposals assume a complete institutional blank slate. One recent example of the neglect of the status quo is a comment made by Ambassador Lewis Lucke, who directed U.S. relief efforts in Haiti: "It's ironic, but after the immense suffering, we do have an opportunity. Haiti is now so profoundly broken there is really a chance to put it back together in a way that all of the well intentioned developmental programs of the past would not have done" (quoted in Bay 2010). While it is true that a crisis can dislodge vested interests, it is incorrect to conclude that this results in a complete institutional blank slate; evolved cultural rules still exist even if certain institutions are damaged or destroyed. A crisis can create space for the reform of rules, but these reforms are constrained by evolved rules which still exist in the post-crisis period. Indeed, the major rule reforms that took place in post-World War II Japan and Germany were effective precisely because they worked within the existing status quo (see Coyne 2007).

To provide another example, consider the case of Iraq, where following the overthrow of Saddam Hussein, reformers attempted to simultaneously undertake meta-reforms to economics, legal political, and social institutions while engaging in widespread reconstruction to foster economic development. Reformers not only neglected the status quo, but also missed opportunities for simpler reforms that were more realistic and could have had a potentially large impact. Consider that as of 2010 — seven years after the initial invasion-Iraq ranked 153 out of 183 rated countries in the World Bank's annual "Doing Business" index, which measures how burdensome business regulations are in each country (World Bank 2010). Reforms aimed at easing these regulations are more realistic as compared to wholesale changes. 
Buchanan's analysis of politics after the collapse of socialism also provides insight into his broader view of the reforms required to achieve the "good society," characterized by liberty, peace, prosperity, and justice. First, citizens and reformers must remove the romantic blinders regarding what politics can actually achieve. Second, there must be an appreciation of Adam Smith's “obvious and simple system of natural liberty," which minimizes political interference in economic activity. Third, there must be adequate constitutional constraints to limit the "ordinary politics of majoritarian democracy..." (Buchanan 1990: 316). However, the feasibility of these reforms will be constrained by the context-specific status quo.

Brennan and Buchanan (1985) emphasize that the potential for genuine constitutional reforms are largely a function of the reform's perceived legitimacy and effectiveness. This leads to an interesting if "...somewhat ironic result...that it may be much easier for a country to achieve genuine constitutional revolution if its citizenry has long adhered to a 'constitutional attitude,' fostered by a historical record during which limits on the power of governments have proved effective to at least some degree" (Buchanan 1985: 143). Ultimately, this implies that societies that appear to be most in need of "genuine constitutional revolution"- such as Haitiare the same places where such reforms are least likely to be effective.

All of this points to the difficulties of attempting to change the attitudes and belief systems of citizens, as well as fostering wide-spread and genuine constitutional change. But this does not mean that all is lost. As the long history of romantic constructivism illustrates, simply recognizing that there are constraints on what can be achieved-a task that is relatively simple compared to cultural and constitutional reform - is a victory in itself. Indeed, as the socialist project demonstrated, the failure to ignore basic constraints about what man can achieve can result in "...irrevocable harm...imposed on all persons in the international social nexus." And 
appreciating the limits imposed by constraints so that this harm can be avoided "...is as important as recognizing the potential that may be achieved within those limits" (Buchanan 1990: 317). The recognition of existing constraints must be at the center of any discussion of the reform of rules following crisis.

\section{Concluding Remarks}

James Buchanan's work provides the foundations for a constitutional political economy of crisis. This has important implications for our understanding of how societies cope with crises and how crises affect societies. First, crises are inevitable, and a society's ability to cope with their adverse effects is a function of the existing rules, which frame the behavior of the state and private citizens. This may appear obvious, but the uncertainty of when a crisis will occur, combined with the urgency to do something when a crisis does occur, tends to lead to a neglect of the importance of rules for shaping and constraining the behavior of the state.

Second, a society's resilience to crises is largely a function of the state's protection of basic rights and the degree to which this protection encourages entrepreneurial dynamism. Entrepreneurship in the pre-crisis period allows for increases in wealth that mitigate the negative effects of crises. They also encourage crisis-specific entrepreneurial activity. Freedom to associate before, during, and after a crisis strikes is critical in allowing citizens to develop and take advantage of social networks and associations which can ease the immediate effects of crises and facilitate recovery.

A third implication is that crises can lead to changes both within the political constitution, and also to the political constitution itself. The main threat posed by crises is that they will erode the rules established by the political constitution which constrains state activity, resulting in 
constitutional anarchy. There are at least two solutions to these potential threats. First, citizens can become better informed regarding the costs of expanded state activity, which may lead them to be less willing to grant increased decision-making powers to politicians during times of crisis. Second, constitutional constraints can limit the ability of the state to permanently expand the scope of its activities during times of crisis. Effective constraints would limit the potential damage done by crisis-time decisions, which are often made hastily and with a lack of information and debate. Examples of potential constraints include a sunset provision in all new crisis-related measures (see Congleton 2005; Higgs 2009), the consistent application of the generality principle (see Hayek 1960; Buchanan and Congleton 1998), and effective checks and balances to limit the reach of state activities (see Weingast 1995).

A fourth implication is that crises may present an opportunity for the reform of rules. The extent and nature of reforms are limited by existing constraints on human behavior, including evolved cultural rules and historical experiences. Neglecting the "here and now" will result in romantic constructivism and a higher likelihood that reforms will either be dysfunctional or that they will altogether fail. The failure to appreciate human nature as it is explains the failure and tragedies associated with many efforts to reform and improve institutions throughout human history. Perhaps more importantly, the neglect of constraints when considering constitutional alternatives runs the risk of planting the seeds of a future crisis, the prevention of which is the very purpose of the reform of rules in the first place. 


\section{References}

Acemoglu, Daron and Simon Johnson. 2005. "Unbundling Institutions," Journal of Political Economy, 113(5), 949-995.

Bay, Austin. 2010. “Haiti After the Quake: Opportunity for Renewal?” June 16, Published online: http://www.realclearpolitics.com/articles/2010/06/16/haiti_after the quake opportunity for_renewal_105971.html

Beito, David T. 2000. From Mutual Aid to the Welfare State: Fraternal Societies and Social Services, 1890-1967. Chapel Hill: The University of North Carolina Press.

Besley, Timothy and Robin Burgess. 2002. "The Political Economy of Government Responsiveness: Theory and Evidence from India," Quarterly Journal of Economics 117(4): 1415-1451.

Brennan, Geoffrey and James M. Buchanan. 1985. The Reason of Rules: Constitutional Political Economy. Cambridge: Cambridge University Press.

Buchanan, James. M. 1975 [2000]. The Limits of Liberty: Between Anarchy and Leviathan. Indianapolis: Liberty Fund, Inc.

. 1990 [2001]. "The Potential for Politics after Socialism," In, The Collected Works of James M. Buchanan, Volume 19, Ideas, Persons, and Events. Indianapolis, Liberty Fund, Inc., pp. 304-317.

. 2004. “The Status of the Status Quo," Constitutional Political Economy 15(2): 133-144.

Buchanan, James M. and Roger D. Congleton. 1998. Politics by Principle, Not Interest. Massachusetts: Cambridge University Press.

Buchanan, James M., Robert D. Tollison and Gordon Tullock (eds.). 1980. Toward a Theory of the Rent-Seeking Society. College Station: Texas A\&M Press.

Chamlee-Wright, Emily. 2010. The Cultural and Political Economy of Recovery: Social Learning in a Post-Disaster Environment. New York, NY: Routledge.

Chamlee-Wright, Emily and Virgil Storr. 2010. "Expectations of Government's Response to Disaster," Public Choice 144(1-2): 253-274.

Congleton, Roger. 2005. "The Political Economy of Crisis Management: Surprise, Urgency, and Mistakes in Political Decision Making," Advances in Austrian Economics 8 (2005): 183204.

. 2006. "The Story of Katrina: New Orleans and the Political Economy of Catastrophe," 
Public Choice 127(2-3): 5-30.

. 2009. "On the Political Economy of the Financial Crisis and Bailout of 2008-09," Public Choice 140(3-4): 287-317.

Corwin, Edward S. 1947. Total War and the Constitution. New York: Alfred A. Knopf.

Coyne, Christopher J. 2007. After War: The Political Economy of Exporting Democracy. California: Stanford University Press.

Coyne, Christopher J. and Peter T. Leeson. 2009. Media, Development, and Institutional Change. Cheltenham, UK: Edward Elgar Publishing, Ltd.

Diamond, Jared. 2005. Collapse: How Societies Choose to Fail or Succeed. New York: Penguin Group.

Easton, Steven T. and Michael A. Walker. 1997. "Income, Growth, and Economic Freedom," American Economic Review 87(2): 328-332.

Ferguson, Niall. 2010. "Complexity and Collapse: Empires on the Edge of Chaos," Foreign Affairs 89(2): 18-32

Haggard, Stephan. 2000. The Political Economy of the Asian Financial Crisis. Washington, DC: The Institute for International Economics.

Hall, Robert E., and Charles I. Jones. 1999. "Why Do Some Countries Produce So Much More Output per Worker Than Others?" Quarterly Journal of Economics, 114: 83-116.

Hausken, Kjell and Thomas Plumper. 2002. "Containing Contagious Financial Crises: The Political Economy of Joint Intervention into the Asian Crisis," Public Choice 111(3/4): 209-236.

Hayek, F.A. 1960. The Constitution of Liberty. Chicago: University of Chicago Press.

Higgs, Robert. 1987. Crisis and Leviathan: Critical Episodes in the Growth of American Government. New York: Oxford University Press.

. 1997. "Regime Uncertainty: Why the Great Depression Lasted So Long and Why Prosperity Resumed After the War," The Independent Review 1(4): 561-590.

. 2007. Neither Liberty Nor Safety: Fear, Ideology, and the Growth of Government. Oakland, CA: The Independent Institute. . 2009. "The Political Economy of Crisis Opportunism," Policy Primer No. 11. Mercatus Center, Arlington, VA. 
Horwitz, Steven. 2009. "Wal-mart to the Rescue: Private Enterprise's Response to Hurricane Katrina," The Independent Review 13(4): 511-528.

Kahn, Mathew E. 2005. "The Death Toll From Natural Disasters: The Role of Income, Geography, and Institutions," Review of Economics and Statistics 87(2): 271-284.

Keefer, Philip. 2007. "Elections, Special Interests, and Financial Crisis," International Organization 61(3): 607-641.

Mises, Ludwig von. 1944 [1983]. Bureaucracy. Grove City: Libertarian Press, Inc.

Mueller, John. 2006. Overblown: How Politics and the Terrorism Industry Inflate National Security Threats, and Why We Believe Them. New York: Free Press.

Navarro, Peter. 1984. The Policy Game: How Special Interests and Ideologues are Stealing America. New York: Wiley.

Niskanen, William N. 1971. Bureaucracy and Representative Government. Aldine: Atherton.

Olson, Mancur. 1984. The Rise and Decline of Nations. Connecticut: Yale University Press.

Posner, Richard A. 2004. Catastrophe: Risk and Response. New York: Oxford University Press.

Satyanath, Shanker. 2005. Globalization, Politics, and Financial Turmoil: Asia's Banking Crisis. Cambridge: Cambridge University Press.

Scully, Gerald. 1988. "The Institutional Framework and Economic Development," The Journal of Political Economy, 96(3): 652-662.

Seeger, Matthew W., Timothy L. Sellnow and Robert R. Ulmer. 1998. "Communication, Organization, and Cisis," In M.E. Roloff, (ed.), Communication Yearbook, Vol 21, California: Sage, pp. 231-275.

Sen, Amartya. 1984. "Food Battles: conflicts in the access to food," Food and Nutrition 10(1): 81-89.

Shughart, William F. 2006. "Katrinanomics: The Politics and Economics of Disaster Relief," Public Choice 127(2-3): 31-53.

Siegan, Bernard H. 2006. Economic Liberties and the Constitution. New Jersey: Transaction Publishers.

Sobel, Russell S. and Peter T. Leeson. 2006. "Government's Response to Hurricane Katrina: A Public Choice Analysis," Public Choice 127(2-3): 55-73.

Tocqueville, Alexis de. 1835/1939 [1969]. Democracy in America, Vols 1 and 2. J.P. Mayers 
(ed.) and George Lawrence (trans.). New York: Doubleday.

Tullock, Gordon. 1965 [2005]. The Politics of Bureaucracy. In C. Rowley (Ed.), The selected works of Gordon Tullock: Vol. 6. Bureaucracy (pp. 13-235). Indianapolis: Liberty Fund.

Weingast, Barry. 1995. "The Economic Role of Political Institutions: Market-Preserving Federalism and Economic Development," Journal of Law, Economics, \& Organization 20(1): 1-31.

World Bank. 2010. "Doing Business," available at:

http://www.doingbusiness.org/economyrankings/ 